\title{
Evaluation of Maturity Level of the Electronic based Government System in the Department of Industry and Commerce of Banjar Regency
}

\author{
M. Rizeki Yuda Saputra ${ }^{1}$, Wing Wahyu Winarno ${ }^{2}$ Henderi $^{3}$, Syahrial Shaddiq ${ }^{4}$ \\ ${ }^{1,3}$ Universitas Amikom Yogyakarta \\ ${ }^{2}$ School of Economics (STIE) YKPN Yogyakarta \\ ${ }^{4}$ Universitas Islam Indonesia (UII) Yogyakarta \\ ${ }^{1}$ mrizeky.ax@gmail.com, ${ }^{2}$ wingwahyuwinarno@gmail.com, ${ }^{3}$ henderi@ mail.ugm.ac.id, \\ ${ }^{4} 17931001 @$ students.uii.ac.id
}

\begin{abstract}
This research was conducted to determine the progress achieved and provide suggestions for the implementation of the EBGS service domain in the Banjar Regency Industry and Trade Office. The Electronic Based Government System (EBGS) assessment structure is specific to the Domain 3 EBGS service maturity level in the capability of the function and uses the Capability Maturity Model/Capability Maturity Model Integration (CMM/CMMI) Development method. The EBGS Service domain index calculation is based on the results of data processing from 12 respondents on the EBGS questionnaire, then CMMI Roadmap is mapped based on the EBGS service domain which has the highest conformity value used as the most suitable roadmap, which in this study is the Process Roadmap which then measures the level of maturity of each process area (Process Area Organizational Process Focus, Process Area Organizational Focus Definition, Process Area Measurement and Analysis, Process Area Causal Analysis and Resolution, Process Area Process and Product Quality Assurance). Recommendations are given based on the results of calculating the level of maturity of each Process Area so that the suggestions given can be used as appropriate and sustainable corrective measures for the relevant agencies.
\end{abstract}

Keywords- Domain 3 SPBE Services, CMM/CMMI Development, Process Roadmap, Process Area.

\section{INTRODUCTION}

EBGS is intended to create efficient, effective, transparent, and accountable work processes and improves the quality of public services. The purpose of the EBGS evaluation is to find out the progress of the implementation of the EBGS at the Central Agency and Regional Government, provide suggestions for improvements to improve the quality of the implementation of the EBGS, and ensure the quality of the implementation of the EBGS evaluation at the Central Agency and Regional Government. It is necessary to conduct periodic evaluations to determine the extent of the progress of EBGS implementation in each Central Agency and Regional Government to reach the objective of the EBGS. The quality of EBGS in Indonesia is measured by various methods of maturity, namely Capability Maturity Model/Capability Maturity Model Integration and Electronic Government Maturity Models [1]. CMM/CMMI is a model that measures the maturity level of the software development process, while E-Government Maturity Model is a maturity level model that measures the evolution of EBGS viewed from the aspects of functionality and technical capability. The most widely used method is CMM/CMMI [2]. CMMI can benefit from, among others, an increase in effective and efficient assessments in various disciplines and a reduction of training and assessment costs [2]. Referring to the CMMI for development guide, the continuous model offers high flexibility for an organization using CMMI to carry out the software improvement process. Organizations are allowed to choose process areas either based on the problem or randomly for a particular need without complying with the path represented by the STAGED model to be more targeted in aligning with the company's business goals [3]. CMMI - Dev is based on the CMMI model and combines work with development organizations to adopt CMMI for use in product and service development [4]. Based on the previous research used as a reference, in this study, the measurement of the level of maturity of retail companies was conducted where the average level of maturity produced was still at the level of maturity-1 [5]. The research conducted uses the CMMI method and is expected to know the progress of the implementation of the EBGS at the Central Agency and Local Government, in this case, the Banjar District and the OPD Department of Industry and Trade. Banjar Regency through the Regional Medium-Term Development Plan has formulated one of its visions, which is related to the development of e-government, which reads implementing an information system of planning, budgeting, procurement, control, and evaluation consistently. Currently, the Banjar Regency government has tried to continue to realize the vision and mission by making information systems that aim to make work more computerized. However, the Banjar Regency government does not know whether they are at the level of good or bad indicators to perceive the achievements or indicators of the development of the e-government itself. Therefore, there must be an evaluation instrument. The Central Government, which sees the problem through the Ministry of Administrative Reform and Bureaucratic Reform, has issued an evaluation guideline for the Electronic Based Government System (EBGS) following the Minister of 
PANRB Regulation Number 5, year 2018, followed by Presidential Decision number 95/2018 Chapter 1. EBGS evaluation is the process of evaluating the implementation of EBGS in Central and Local Government Agencies to produce an EBGS index that describes the level of Information Technology maturity [1]. Therefore, in this study, the researchers tried to raise the issue through the Regional Office of the Department of Industry and Commerce of the Banjar Regency and were expected to become a reference document for other OPDs. This research is also expected to be a reference for the Regional Strategic Plan, namely RPJMD in terms of vision and mission regarding IT, namely implementing, planning, budgeting, procurement, control, and evaluation (e-governance) information system consistently, as stated in the Regional Regulation on RPJMD Banjar Regency in 2016-2021.

\section{RESEARCH METHOD}

The method of data collection were observation, interviews, and questionnaires. The data analysis method was used to evaluate the EBGS CMMI method, following the Ministry Regulation number 5, 2018. This method would later become an EBGS evaluation instrument according to the EBGS, namely planning, implementation, and reporting. CMMI measured the level of maturity in the process capability. The measurement values of each level of maturity were Level 1, given a value of 1, Level 2, given a value of 2 , Level 3, given a value, Level 4, given a value of 4, and Level 5 , given a value of 5 , according to the 5 Maturity Levels. Level 1 was Initial, Level 2 Managed, Level 3 Defined, Level 4 Quantitatively Managed, and Level 5 Optimizing.

The flow of research in each stage was adjusted to the CMMI framework. Figure 1 displays the research flow
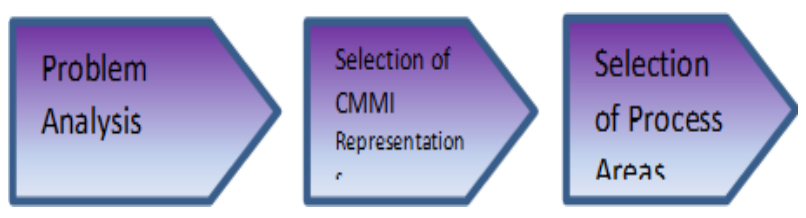

Fig. 1. Research Flow

Figure 1 illustrates the research flow which is divided into three stages. The first stage is the problem analysis (the initial process at the data collection to find the source of the problem, collected based on deeper observation, and it is a part of the results of the interview to the representation and selection of the process area). The second stage is the selection of CMMI representation (planning and preparation for the assessment process by preparing speakers and collecting data needed for the assessment process). It uses reasoning results that are reasonable on the criteria in each representation adapted to the observation results. The final stage is the process selection (the final process by selecting the CMMI process area by using the guidelines from the SEI, namely CMMI Roadmap by looking for conformity using the conformity matrix [6].

\section{RESULTS AND DISCUSSION}

The case study was an enterprise engaged in the Government sector, namely the Department of Industry and Trade of the Banjar Regency, elaborated previously in the general description section of the research object. It focused on the capability maturity level, namely the domain-3 EBGS services displayed in table 1 , and the characteristics of the maturity level presented in table 2 . Weights were given to the domains and aspects according to different levels of importance. The weighing value of the EBGS service domain was $55 \%$, the EBGS governance domain was $28 \%$, and the EBGS internal policy domain was $17 \%$. Table 3 presents the Domain-3 weight and aspects, while the weight value of each indicator in an aspect was calculated from the aspect weight value, divided by the number of indicators in that aspect. The index values that presented the maturity level of SBE implementation were grouped based on the predicate, as presented in table 4.

TABLE I. DOMAIN 3 SPBE SERVICES CAPABILITy MATURITy LEVEL FUNCTION

\begin{tabular}{|l|l|}
\hline Domain 3 & SPBE Services \\
\hline Aspect 6 & $\begin{array}{l}\text { Electronic-based Government Administration } \\
\text { Services }\end{array}$ \\
\hline Indicator 25 & Service Script Services \\
\hline Indicator 26 & Staffing Management Services \\
\hline Indicator 27 & Planning Management Services \\
\hline Indicator 28 & Budgeting Management Services \\
\hline Indicator 29 & Financial Management Services \\
\hline Indicator 30 & Performance Management Services \\
\hline Indicator 31 & Procurement Services \\
\hline Aspect 7 & Electronic-based Public Services \\
\hline Indicator 32 & Public Complaints Service \\
\hline Indicator 33 & Legal Documentation and Information Services \\
\hline Indicator 34 & Whistleblowing System Service \\
\hline Indicator 35 & Public Service Government Agencies \\
\hline
\end{tabular}

TABLE II. SPBE SERVICE DOMAIN MATURITY LEVEL

\begin{tabular}{|l|l|}
\hline \multicolumn{1}{|c|}{ Level } & \multicolumn{1}{c|}{ Criteria } \\
\hline 1 - Information & $\begin{array}{l}\text { SPBE services are provided in the form of one-way } \\
\text { information }\end{array}$ \\
\hline 2 - Interaction & $\begin{array}{l}\text { SPBE services are provided in the form of two-way } \\
\text { information }\end{array}$ \\
\hline 3 - Transaction & $\begin{array}{l}\text { SPBE services are provided through information } \\
\text { exchange services }\end{array}$ \\
\hline 4 - Collaboration & $\begin{array}{l}\text { SPBE services are provided through integration } \\
\text { with other SPPBE services }\end{array}$ \\
\hline 5 - Optimalisation & $\begin{array}{l}\text { SPBE services can adapt to changing needs in the } \\
\text { internal and external environment }\end{array}$ \\
\hline
\end{tabular}

TABLE III.

DOMAIN VALUE WEIGHT AND SPBE ASPECT

\begin{tabular}{|l|c|c|}
\hline \multicolumn{1}{|c|}{ Domain and Rating Aspects } & $\begin{array}{c}\text { Number of } \\
\text { Indicators }\end{array}$ & $\begin{array}{c}\text { Total } \\
\text { Weight }\end{array}$ \\
\hline Domain 3 - SPBE Services & 11 & $55 \%$ \\
\hline $\begin{array}{l}\text { Aspect 6 - Electronic-based } \\
\text { Government Administration Services }\end{array}$ & 7 & $35 \%$ \\
\hline $\begin{array}{l}\text { Aspect 7 - Electronic-based Public } \\
\text { Services }\end{array}$ & 4 & $20 \%$ \\
\hline
\end{tabular}

TABLE IV.

SPBE INDEX PREDICATE

\begin{tabular}{|c|c|c|}
\hline No. & Index Value & Predicate \\
\hline 1. & $4.2-5.0$ & Satisfying \\
\hline 2. & $3.5-<4.2$ & Very Good \\
\hline 3. & $2.6-<3.5$ & Well \\
\hline 4. & $1.6-<2.6$ & Enough \\
\hline 5. & $<1.8$ & Less \\
\hline
\end{tabular}


The results of the questionnaire calculation focusing on the domain 3 of EBGS Services in the Department of Industry and Commerce Banjar Regency can be seen in Table 5, Table 6, and Figure 2.

\section{TABLE V.}

ASPECT INDEX ASSESSMENT RESULTS IN DOMAIN 3 SPBE SERVICES

\begin{tabular}{|l|c|}
\hline \multicolumn{1}{|c|}{ Service Domain Index } & $\mathbf{1 . 1 5}$ \\
\hline \multicolumn{1}{|c|}{ Aspect } & Index \\
\hline Government Administration Services & 1.43 \\
\hline Public Service & 0.67 \\
\hline
\end{tabular}

TABLE VI

INDEX ASSESSMENT RESULTS PER INDICATOR IN DOMAIN 3 OF SPBE SERVICES

\begin{tabular}{|l|c|}
\hline \multicolumn{1}{|c|}{ Indicator } & Index \\
\hline Official Script & 1.00 \\
\hline Staffing & 2.00 \\
\hline Planning & 1.00 \\
\hline Budgeting & 1.00 \\
\hline Finance & 1.00 \\
\hline Performance Accountability & 1.00 \\
\hline Procurement & 3.00 \\
\hline Public Complaints & 1.00 \\
\hline Public Service 1 & 1.00 \\
\hline Public Service 2 & 1.00 \\
\hline Public Services 3 & 1.00 \\
\hline IDL & 1.15 \\
\hline
\end{tabular}

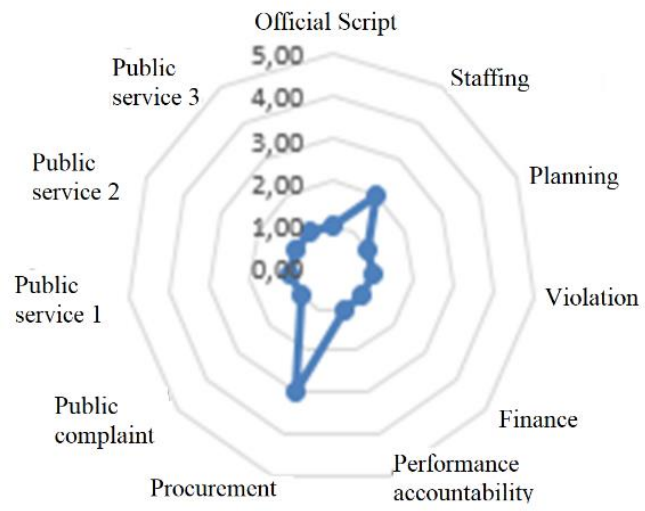

Fig. 2. Domain Radar Chart 3 SPBE Service Index

The objectives to be improved related to SPBE in the Department of Industry and Commerce Banjar Regency include: a more efficient service script system; a better and responsive staffing management system; broader system of planning and budgeting management activities; an effective and efficient performance management system; evaluative public complaints service system; as a facility for the Small and Medium Industries (IKM) to develop and promote superior products. Of the six objectives, then mapped to determine the roadmap that will be used. The relevance matrix can be seen in Table 7 .

TABLE VII. RELEVANCE MATRIX CRITERIA AND CHARACTERISTICS OF THE CMMI ROADMAP

\begin{tabular}{|c|c|c|c|c|c|}
\hline Criteria & $\begin{array}{c}\text { Project } \\
\text { Roadmap }\end{array}$ & $\begin{array}{c}\text { Product } \\
\text { Roadmap }\end{array}$ & $\begin{array}{c}\text { Product } \\
\text { Integration } \\
\text { Roadmap }\end{array}$ & $\begin{array}{c}\text { Process } \\
\text { Roadmap }\end{array}$ & $\begin{array}{l}\text { Measurement } \\
\text { Roadmap }\end{array}$ \\
\hline $\begin{array}{l}\text { A more } \\
\text { efficient } \\
\text { official } \\
\text { script } \\
\text { system. }\end{array}$ & - & - & - & $\sqrt{ }$ & - \\
\hline $\begin{array}{l}\text { A better } \\
\text { and } \\
\text { responsive } \\
\text { staffing } \\
\text { managemen } \\
\text { t system. }\end{array}$ & $\sqrt{ }$ & - & - & $\sqrt{ }$ & - \\
\hline $\begin{array}{l}\text { Broader } \\
\text { planning } \\
\text { and } \\
\text { budgeting } \\
\text { managemen } \\
\text { t system. }\end{array}$ & $\sqrt{ }$ & - & - & $\sqrt{ }$ & $\sqrt{ }$ \\
\hline $\begin{array}{l}\text { An } \\
\text { effective } \\
\text { and } \\
\text { efficient } \\
\text { performanc } \\
\text { e } \\
\text { managemen } \\
\text { t system. }\end{array}$ & $\sqrt{ }$ & - & - & $\sqrt{ }$ & $\sqrt{ }$ \\
\hline $\begin{array}{l}\text { Evaluative } \\
\text { public } \\
\text { complaint } \\
\text { service } \\
\text { system. }\end{array}$ & - & - & - & $\sqrt{ }$ & - \\
\hline $\begin{array}{l}\text { As a } \\
\text { facility for } \\
\text { SMEs } \\
\text { (Small and } \\
\text { Medium } \\
\text { Entrepri } \\
\text { ses) to } \\
\text { develop and } \\
\text { promote } \\
\text { regional } \\
\text { superior } \\
\text { product. }\end{array}$ & - & $\sqrt{ }$ & - & - & - \\
\hline Results & 3 & 1 & 0 & 5 & 2 \\
\hline
\end{tabular}

Table 7 displays the process roadmap, which has the highest level of conformity. With the process area approach that refers to the CMMI roadmap, the identification of process areas was directed at the roles associated with EBGS services in the Department of Industry and Commerce Banjar District to get an answer to the true EBGS maturity level in the field. Table 8 presents five process areas in this study.

TABLE VIII. $\quad$ Best Practice Key Process AREa CMMI

\begin{tabular}{|c|l|l|}
\hline Process Area & \multicolumn{1}{|c|}{ Spesific Practice } & Generic Practice \\
\hline \multirow{2}{*}{ OPF } & $\begin{array}{l}\text { SP 1.1 Establish } \\
\text { organisational } \\
\text { process needs. }\end{array}$ & $\begin{array}{l}\text { GP 2.9 Objectively } \\
\text { evaluate compliance. }\end{array}$ \\
\cline { 2 - 3 } & $\begin{array}{l}\text { SP 2.2 Implement } \\
\text { the action plan } \\
\text { process. }\end{array}$ & $\begin{array}{l}\text { GP 3.2 Collecting the } \\
\text { relationship process. }\end{array}$ \\
\hline OPD & $\begin{array}{l}\text { SP 1.1 Establish } \\
\text { process standards. }\end{array}$ & \\
\hline
\end{tabular}




\begin{tabular}{|c|l|c|}
\hline Process Area & \multicolumn{1}{|c|}{ Spesific Practice } & Generic Practice \\
\hline \multirow{4}{*}{ MA } & $\begin{array}{l}\text { SP 1.7 Establish } \\
\text { rules and guidelines } \\
\text { for the team. }\end{array}$ & \\
\hline \multirow{5}{*}{ CAR } & $\begin{array}{l}\text { SP 1.1 Establish } \\
\text { measurement } \\
\text { objectives. }\end{array}$ & \\
\hline \multirow{5}{*}{ PPQA } & $\begin{array}{l}\text { SP 1.1 Select results } \\
\text { for analysis. }\end{array}$ & \\
\cline { 2 - 3 } & $\begin{array}{l}\text { SP 2.3 Record cause } \\
\text { and effect from data } \\
\text { analysis. }\end{array}$ & \\
\hline & $\begin{array}{l}\text { SP 1.1 Evaluate the } \\
\text { process area. }\end{array}$ & \\
\cline { 2 - 3 } & $\begin{array}{l}\text { SP 1.2 Evaluate } \\
\text { products and } \\
\text { services objectively. }\end{array}$ & \\
\hline
\end{tabular}

TABLE IX.

RECAPITULATION OF NUMBER OF QUESTIONS MAPPED TO EACH PROCESS AREA

\begin{tabular}{|c|c|}
\hline Process Area & Number of Questions \\
\hline OPF & 2 \\
\hline OPD & 2 \\
\hline MA & 1 \\
\hline CAR & 2 \\
\hline PPQA & 3 \\
\hline Total Questions & 10 \\
\hline
\end{tabular}

TABLE X.

MEASUREMENT OF OPF PRocess AREA ACHIEVEMENT VALUES

\begin{tabular}{|c|c|c|}
\hline \multirow{2}{*}{$\begin{array}{c}\text { Respondents } \\
\text { to- }\end{array}$} & Weight per Questionnaire \\
\cline { 2 - 3 } & Question 1 & Question 2 \\
\hline 1 & 2 & 2 \\
\hline 2 & 2 & 2 \\
\hline 3 & 2 & 2 \\
\hline 4 & 2 & 2 \\
\hline 5 & 2 & 2 \\
\hline 6 & 2 & 2 \\
\hline 7 & 2 & 2 \\
\hline 8 & 2 & 2 \\
\hline 9 & 2 & 2 \\
\hline 10 & 2 & 2 \\
\hline 11 & 2 & 2 \\
\hline 12 & 2 & 2 \\
\hline Amount & 24 & 24 \\
\hline Score & \multicolumn{2}{|c}{} \\
average & 4.00 \\
\hline PA value & \multicolumn{2}{|c|}{2.00} \\
\hline
\end{tabular}

The questionnaire identification taken in this study was adjusted to the selected process area, namely the Organisational Process Focus (OPF), OPD, Measurement Analysis (MA), Causal Analysis and Resolution (CAR), and Process and Product Quality Assurance (PPQA). Table 9 illustrates the recapitulation of the number of questions mapped to each process area.

The identification of the answers of the EBGS questionnaire resulted in the achievement value of each process area is presented in table 10,11, and 12 .

TABLE XI. MEASUREMENT OF ACHIEVEMENT VALUE OF OPD

\begin{tabular}{|c|c|c|}
\hline \multirow{2}{*}{$\begin{array}{c}\text { Respondents } \\
\text { to- }\end{array}$} & \multicolumn{2}{|c|}{ Weight per Questionnaire } \\
\cline { 2 - 3 } & Question 3 & Question 4 \\
\hline 1 & 1 & 2 \\
\hline
\end{tabular}

\begin{tabular}{|c|c|c|}
\hline \multirow{2}{*}{$\begin{array}{c}\text { Respondents } \\
\text { to- }\end{array}$} & \multicolumn{2}{|c|}{ Weight per Questionnaire } \\
\cline { 2 - 3 } & Question 3 & Question 4 \\
\hline 2 & 1 & 2 \\
\hline 3 & 2 & 2 \\
\hline 4 & 2 & 1 \\
\hline 5 & 1 & 2 \\
\hline 6 & 1 & 2 \\
\hline 7 & 2 & 2 \\
\hline 8 & 2 & 1 \\
\hline 9 & 2 & 1 \\
\hline 10 & 1 & 1 \\
\hline 11 & 2 & 1 \\
\hline 12 & 2 & 18 \\
\hline Amount & 19 & \\
\hline Score & \multicolumn{2}{|c|}{} \\
\hline average & \multicolumn{2}{|c|}{1.54} \\
\hline PA value & \multicolumn{2}{|c|}{} \\
\hline \multicolumn{2}{|c|}{} \\
\hline
\end{tabular}

TABLE XII. MEASUREMENT OF THE ACHIEVEMENT VALUE OF THE MA PROCESS AREA

\begin{tabular}{|c|c|}
\hline \multirow{2}{*}{$\begin{array}{c}\text { Respondents } \\
\text { to- }\end{array}$} & $\begin{array}{c}\text { Weight per } \\
\text { Questionnaire }\end{array}$ \\
\cline { 2 - 2 } & Question 5 \\
\hline 1 & 1 \\
\hline 2 & 1 \\
\hline 3 & 1 \\
\hline 4 & 2 \\
\hline 5 & 2 \\
\hline 6 & 2 \\
\hline 7 & 1 \\
\hline 8 & 1 \\
\hline 9 & 1 \\
\hline 10 & 2 \\
\hline 11 & 2 \\
\hline 12 & 1 \\
\hline Amount & 17 \\
\hline Score & 1.42 \\
\hline average & 1.42 \\
\hline PA value & \\
\hline
\end{tabular}

\section{CONCLUSION}

The index value of EBGS service domain maturity level assessment at the Department of Industry and Commerce Banjar Regency is 1.27 , the government administration service aspects index is 1.43 , and the public service aspects index is 1 . The results of the study indicate that the implementation of the electronic-based government system by the Department of Industry and Commerce of Banjar Regency is still at the maturity level 1, namely Information in the scheme of One-Way Information. Based on the problem identification, the assessment of the EBGS service index still requires improvement. Therefore, the CMMI method is used to guide the process improvement in the project, division, or the whole organization. It integrates the traditional functions of separate organizations, determines the process of improving organizational goals and priorities, manages the quality of organizational processes, and provide referrals for assessing organizational processes. The average value of EBGS service maturity is 1.52 , which shows that the

M. Rizeki Yuda Saputra, Evaluation of Maturity Level of the Electronic based Government System in the Department of Industry and Commerce of Banjar Regency 
management of the EBGS services has been done in a performed process.

\section{SUGGESTION}

The Banjar Regency Industry Office is expected to immediately implement the existing recommendations for process improvement to implement the optimal and targeted EBGS services, continuously evaluate EBGS services as oversight of existing processes so that they can become a reference for making decisions, and use the CMMI DEV framework as a reference so that the EBGS service system can be more optimal and targeted. Recognizing the level of EBGS service maturity in the Department of Industry and Commerce, Banjar Regency is essential to improve the service to realize one of the visions and missions of the Banjar Regency RPJMD, namely to implement the planning, budgeting, procurement, and evaluation of the e-government information system continuously. Besides, the EBGS evaluation can be used as a reference for other OPDs in Banjar Regency and as a benchmark for future research using the EBGS questionnaire.

\section{ACKNOWLEDGMENT}

The author would like to thanks a lot to my supervisor, namely Dr. Drs. Wing Wahyu Winarno, MAFIS., Ak. (Academician of YKPN, AMIKOM, UGM, \& UII) and the co-supervisor, namely Mr. Henderi, S.Kom., M.Kom. (Academician of AMIKOM) who have taken the time to guide the author in the thesis research and writing in the journal article conducted by the author in the Master of Informatics Engineering (MTI) Study Programme at the University of AMIKOM Yogyakarta. On the other hand, the author would like to thank my friend, namely Mr. Syahrial Shaddiq, S.T., M.Eng., M.M. (Academician of UT, UTY, $\mathrm{UCY}$, \& UNU) who collaborated in writing the Journal of Robotics and Control (JRC) article.

\section{REFERENCES}

[1] F. Iannacci, A. P. Seepma, C. de Blok, and A. Resca, "Reappraising maturity models in e-Government research: The trajectory-turning point theory," J. Strateg. Inf. Syst., vol. 28, no. 3, pp. 310-329, Sep. 2019.

[2] I. Keshta, "A model for defining project lifecycle phases: Implementation of CMMI level 2 specific practice,” J. King Saud Univ. - Comput. Inf. Sci., no. xxxx, Nov. 2019.

[3] F. Selleri Silva et al., "Using CMMI together with agile software development: A systematic review," Inf. Softw. Technol., vol. 58, pp. 20-43, Feb. 2015.

[4] M. Staples, M. Niazi, R. Jeffery, A. Abrahams, P. Byatt, and R. Murphy, "An exploratory study of why organizations do not adopt CMMI,” J. Syst. Softw., vol. 80, no. 6, pp. 883-895, Jun. 2007.

[5] Y. Sun and X. (Frank) Liu, "Business-oriented software process improvement based on CMMI using QFD," Inf. Softw. Technol., vol. 52, no. 1, pp. 79-91, Jan. 2010.

[6] C.-H. Cheng, J.-R. Chang, and C.-Y. Kuo, "A CMMI appraisal support system based on a fuzzy quantitative benchmarks model," Expert Syst. Appl., vol. 38, no. 4, pp. 4550-4558, Apr. 2011.

[7] Kim, S., Kim, H. J., \& Lee, H. An institutional analysis of an egovernment system for anti-corruption: The case of OPEN. Government Information Quarterly, 26(1), 42-50. 2009.

[8] Al-Sebie, M., \& Irani, Z. Technical and organisational challenges facing transactional e-government systems: an empirical study.
Electronic Government, an International Journal, 2(3), 247-276. 2005.

[9] Layne, K., \& Lee, J. Developing fully functional E-government: A four stage model. Government information quarterly, 18(2), 122136. 2001

[10] Rana, N. P., \& Dwivedi, Y. K. Citizen's adoption of an egovernment system: Validating extended social cognitive theory (SCT). Government Information Quarterly, 32(2), 172-181. 2015.

[11] Rana, N. P., Dwivedi, Y. K., Lal, B., Williams, M. D., \& Clement, M. Citizens' adoption of an electronic government system: towards a unified view. Information Systems Frontiers, 19(3), 549-568. 2017.

[12] Warkentin, M., Gefen, D., Pavlou, P. A., \& Rose, G. M. Encouraging citizen adoption of e-government by building trust. Electronic markets, 12(3), 157-162. 2002.

[13] Lambrinoudakis, C., Gritzalis, S., Dridi, F., \& Pernul, G. Security requirements for e-government services: a methodological approach for developing a common PKI-based security policy. Computer communications, 26(16), 1873-1883. 2003.

[14] Fang, Z. E-government in digital era: concept, practice, and development. International journal of the Computer, the Internet and management, 10(2), 1-22. 2002.

[15] Alshomrani, S., \& Qamar, S. Cloud based e-government: benefits and challenges. International Journal of Multidisciplinary Sciences and Engineering, 4(6), 1-7. 2013.

[16] Heeks, R. e-Government as a Carrier of Context. Journal of Public Policy, 25(1), 51-74. 2005.

[17] Ozkan, S., \& Kanat, I. E. e-Government adoption model based on theory of planned behavior: Empirical validation. Government Information Quarterly, 28(4), 503-513. 2011.

[18] Hwang, M. S., Li, C. T., Shen, J. J., \& Chu, Y. P. Challenges in egovernment and security of information. Information \& Security, 15(1), 9-20. 2004.

[19] Heeks, R. e-Government in Africa: Promise and practice. Information polity, 7(2, 3), 97-114. 2002.

[20] Lin, F., Fofanah, S. S., \& Liang, D. Assessing citizen adoption of eGovernment initiatives in Gambia: A validation of the technology acceptance model in information systems success. Government Information Quarterly, 28(2), 271-279. 2011.

[21] Siau, K., \& Long, Y. Synthesizing e-government stage models-a meta-synthesis based on meta-ethnography approach. Industrial Management \& Data Systems. 2005

[22] Kumar, M., \& Sinha, O. P. M-government-mobile technology for egovernment. In International conference on e-government, India (pp. 294-301). 2007.

[23] Ebrahim, Z., \& Irani, Z. E-government adoption: architecture and barriers. Business process management journal. 2005.

[24] Chutimaskul, W., Funilkul, S., \& Chongsuphajaisiddhi, V. The quality framework of e-government development. In Proceedings of the 2nd international conference on Theory and practice of electronic governance (pp. 105-109). December, 2008

[25] Chan, C. M., Hackney, R., Pan, S. L., \& Chou, T. C.. Managing eGovernment system implementation: a resource enactment perspective. European Journal of Information Systems, 20(5), 529541. 2011

[26] Mnjama, N., \& Wamukoya, J. E-government and records management: an assessment tool for e-records readiness in government. The Electronic Library. 2007.

[27] Zhou, Z., \& Hu, C. Study on the e-government security risk management. International Journal of Computer Science and Network Security, 8(5), 208-213. 2008.

[28] Tolbert, C. J., \& Mossberger, K. The effects of e-government on trust and confidence in government. Public administration review, 66(3), 354-369. 2006 
[29] Kushchu, I., \& Kuscu, H. From E-government to M-government: Facing the Inevitable. In the 3rd European Conference on eGovernment (pp. 253-260). MCIL Trinity College Dublin Ireland. July, 2003.
[30] Gupta, M. P., \& Jana, D. E-government evaluation: A framework and case study. Government Information quarterly, 20(4), 365-387. 2003. 